\title{
Bird Flu: A recent threat to human health
}

\author{
Asad U. Khan ${ }^{1,2 *}$ \\ ${ }^{1}$ Interdisciplinary Biotechnology Unit; ${ }^{2}$ Distributed Information Sub Centre Aligarh Muslim University, Aligarh - 202002, \\ India; Asad U. Khan* - Email: huzzi99@hotmail.com; Phone: +91 571 2723088; Fax: +91 571 2721776; \\ * Corresponding author \\ published online April 13, 2006
}

\section{Description:}

With more than 100 million birds either dead from infection or culled, the present outbreak of avian influenza in Asia is unprecedented in size. Influenza virus belongs to the viral family, Orthomyxoviridae having single-stranded RNA genome in an enveloped virion. These viral particles are pleiomorphic and many of them are spherical or ovoid with $80-120 \mathrm{~nm}$ diameter. However, other forms including long filamentous particles (up to $2000 \mathrm{~nm}$ long x 80-120 $\mathrm{nm}$ in diameter) are also known. [1, 2] The outer surface of the particle consists of a lipid envelope with prominent glycoprotein spikes of two types (haemagglutinin (HA), a $135 \AA$ trimer and neuraminidase (NA), a $60 \AA$ tetramer). The inner side of the envelope is lined by a matrix protein. [1] The H5N1 sub-type is the pathogenic avian viral sub-type that has been documented to cause an outbreak of respiratory disease in humans. [3] Earlier studies revealed that chickens infected with the H5N2 virus failed to show evidence of human infection.

During the past 6 years, infection of humans with avian influenza viruses of three subtypes ( $\mathrm{H} 5, \mathrm{H} 7$, and $\mathrm{H} 9)$ has been detected on multiple occasions. [4, 5] In 1997, H5N1 avian influenza viruses transmitted from birds to humans were reported in Hong Kong causing a death toll of 6 in 18 infected persons. [6, 7] Eradication measures were taken by slaughtering of all poultry in Hong Kong. However, a new genotype of the virus (H5N1) emerged at poultries, in Hong Kong during 2000 and 2001. Moreover, in 2003, a novel H5N1 sub-type of influenza virus killed one of two infected humans. The virus transmitted to humans during this outbreak is lethal in chickens. An outbreak of highly pathogenic avian influenza A (H5N1) has recently spread among poultries in South East Asian countries. Moreover, the H5N1 infections caused about 52 human deaths in Vietnam, Thailand, and Cambodia from January 2004 to April 2005. [8]

Fortunately, the transmission of avian influenza virus between humans with a potential to cause a pandemic is not known yet. However, the devastating affects of the H5N1 virus on poultry holdings, and hence on economics and food supply and the possible threat of a pandemic outbreak are eminent. [9] Nonetheless, these viruses lack the ability to 'hop' easily between human. It should be noted that these viruses could effectively change their genome during evolution and thereby acquire the potential ability to spread among humans. Hence, the present situation warrants the need for immediate disease management control measure implementation using good surveillance plans throughout the globe.

\author{
References: \\ [1] http://wwwmicro.msb.le.ac.uk/3035/Orthomyxoviruses.html\#ortho. \\ [2] T. Anwar, S. K. Lal , \& A. U. Khan, In Silico Biology, (2006) \\ [3] W. J. Bean, et al., J Virol., 54:151 (1985) [PMID: 3973976] \\ [4] R. Webby \& R. Webster, Science, 302:1519 (2003) [PMID: 14645836] \\ [5] K. Subbarao, \& J. Katz, Cell Mol. Life Sci., 57:1770 (2000) [PMID: 11130181] \\ [6] E. Claas, et al., Lancet, 351:472 (1998) [PMID: 9482438] \\ [7] K. Subbarao, et al., Science, 279:393 (1998) [PMID: 9430591] \\ [8] http://www.cdc.gov/ncidod/EID/vol11no10/05-0644.htm \\ [9] W. S. Barcley \& M. Zambon, BMJ, 328:238 (2004) [PMID: 14751872]
}

Editorial: A.U. Khan

Citation: Khan, Bioinformation 1(4): 132 (2006) License statement: This is an open-access article, which permits unrestricted use, distribution, and reproduction in any medium, for non-commercial purposes, provided the original author and source are credited. 